\title{
Standard Operating Crime Investigation Traffic Accidents
}

\author{
M Farid Amirullah ${ }^{1}$
}

Abstract. History Traffic in Indonesia can not be separated from the development of the world Automotive technology, which originated from the discovery of the engine with petroleum fuels. In the days of the Dutch East Indies government then ruled Indonesia started bringing vehicles wheel 4 and wheel 2 to Indonesia, causing traffic activity. And when the car and motorcycle multiply causing many problems - the problems of traffic, such as traffic violations and accidents. Given the above, of course of police duties particularly Traffic Police Unit increasingly severe, in the sense of Traffic Police Unit should continue to maintain and improve the technical capacity of the police in order to deal with problems like traffic violations and traffic accidents, in addition to the Police Unit Then Trails should be able to provide a breakthrough in order to increase awareness to the public about the correct procedures and safe traffic and police action to reduce the number of traffic accidents on the road. For that to improve the professionalism and quality of work performed is necessary to standardize the work that will be used as working guidelines called the Standard Operation Procedure (SOP)

Keywords: Standard Operating Procedure; Investigation; Traffice Accident.

\section{Introduction}

Acceleration, implementation Police-led policy of Grand Strategy of the first phase of the second stage tread trust building partnership with background implications of security sector reform, good governance implications and Strive for Excellence is the embodiment of excellent service especially traffic police function. Maximizing the building activities of the technical function of traffic in order to improve service quality excellence through the stabilization of the level of professionalism in order to materialize the traffic police traffic police figure of an independent and modern.

Thus necessary to issue operational standards of service as an effort to anticipate the occurrence of irregularities that may interfere with or degrade the image of the Police in general and the last particular Traffic Police unit in Pekalongan in implementing the tasks of protection, shelter, and law enforcement services to the community.

In carrying out these basic tasks, the traffic police has the following main tasks:

- Traffic Education.

- Traffic Engineering.

- Law Enforcement.

- Registration and Identification.

\section{Research methods}

This study using sociological juridical approach namelylaw in interaction can not be separated from the symptoms that occur in the community. According to Roni Haditijo

\footnotetext{
${ }^{1}$ Student of Master of Law, Universitas Islam Sultan Agung Semarang and Police Member Officer email farid ocre@yahoo.co.id
} 
Soemitro juridical sociological approach is approach that sees the law as a phenomenon which in interaction can not be separated from non-legal factors factor. ${ }^{2}$ This type of research is descriptive research that aims to gain a real picture, clearer, and systematically about the fact - the fact is being investigated.

According to Hilman Hadikusuma, a descriptive study, research that is "depict", where knowledge is still superficial danpengertian researcher of the problems examined, but because of the researcher intends to portray gajalaatau legal events that precisely and clearly he tries to describes research results. ${ }^{13}$

\section{Results And Discussion}

Number of Traffic Accidents Genesis in 2017 by the type of vehicle involved in the accident.

$\begin{array}{ll}\text { - Jeep } & :- \\ \text { - Sedan } & : 2 \\ \text { - Pic ups } & : 4 \\ \text { - Station } & : 13 \\ \text { - Truck } & : 30 \\ - \text { Hold Truck } & : 11 \\ \text { - Bus } & : 12 \\ - \text { Motorcycle } & : 182 \\ \text { - Train } & : 2\end{array}$

Total Personnel Unit of Traffic Accident: 7 Personnel Implementation

\subsection{TPTKP Accident}

Chapter XIV of Law No. 22 of 2009 on Road Traffic and Transport (Art 226 s / d 241). TP scene Accident is a Police Action should be implemented immediately after the occurrence of a lacquer and then in the form of closing and securing the crime scene, for the benefit of investigation further and prevent congestion or Accident then new on the scene such as well as for the creation of safety for officers, victims, evidence and other road users. (Skep Kababinkam Police No.Pol Skep / 32 / II / 2003).

- Closing the scene Accident: Changing and traffic flow arrangements in order to avoid congestion; Installation Police Line (borders); Installation of traffic cone and portable signs; Keeping the status quo at the crime scene; Preventing the emergence of new problems; Provide relief to victims if the victim is still at the crime scene.

- Securing the scene Accident: Prohibits any unauthorized entry into the crime scene that has been demarcated (Police Line); Protect evidence from being lost or damaged; Saving suspects outside the crime scene that has been demarcated (Police Line); Search witnesses and collect information as the investigation materials.

\footnotetext{
${ }^{2}$ Roni Haditijo Soemitro 1989 Metodologi Penelitian Hukum Erlangga Jakarta p. 11

${ }^{3}$ Hilman Hadikusuma 1995 Metode Pembuatan Kertas Kerja atau Skripsi IImu Hukum Mandar Maju Bandung p.10.
} 
- Crime Scene of Accident. The investigator or investigators maid Accident then have to do the crime scene to look for and collect evidence as material evidence investigators in conducting reconstruction. To obtain the chronology Accident then investigator in become evidence and documentation as investigation material is divided into three (3) phases as follows: The Phase before the collision (Pre Crash); Fase at the time of the collision (Crash); The Phase after the collision (Posh Crash).

Accident crime scene is the action or activity - activity after the scene TP implemented with a view to seeking, collecting, analysis and evaluating users information and evidence as well as the identity of the suspect to the members the direction of investigating further. (Skep Kababinkam Police Nopol Skep / 32 / II / 2003).

General 1.Observation.

- Situation environment around the scene of Acciden.

- Situation road at the scene Accident.

- Situation driver (victim / suspect).

- Situation vehicle involved in the accident.

- arrival of the vehicle involved in the accident.

Special 2. Observating

- Observate against environmental situation both the physical environment and the social environment.

- Observate to road conditions.

- Observate to infrastructure such as road signs, street lighting, road markings, road shoulder condition, the security fence and other.

- Observate towards the driver, among others:

- Condition driver before the occurrence of traffic accidents (fatigue, sickness, lack of concentration, the effect of the drug).

- Condition driver after traffic accidents (healthy, minor injuries, serious injuries, died)

- Noting identity of the driver (driver's license and ID card).

- Saving the driver and do interviews / short questions about the incident.

- Observate of the vehicles involved, among others:

- Vehicle documents (registration, STCK and KIR Books).

- Content of vehicle.

- Condition existing fittings in the vehicle (headlights, turn signal, brake, horn, the condition of the wheels and so on).

- Benda / junk collisions in the scene (broken glass, old paint, drops of blood, hair, and so on).

- Making a sign at the scene Accident then.

- To vehicles involved Accident.

- Tovictim Accident then.

- To other evidences.

- To hit point.

- To brakes.

- Ruling Accident scene. Measurement scene Accident aims: 
- To give an overview of the situation as accurately as possible the crime scene to others (prosecutor and judge), although it does not come to the scene.

- To determine the distance / size of the actual situation of the scene with the correct size, it will be easier at the time of the reconstruction.

Things that need to be done in the measurement, among others:

- The principal .period measurement.

- key point / point hit (point X).

- Position of vehicles involved (point of measurement of the front bumper and rear bumper).

- Position of victims.

- Position of evidence

- Long former brake.

- Wide road.

- Making Images / Sketches scene Accident. Making the crime scene sketch drawing Accident then aims:

- As a material consideration in determining whether one of the suspects by Judge.

- As a material for Reconstruction hold if any - time is required.

- Police professionalism in the investigation of the case Accident then.

- For the benefit of handling insurance claims.

- Opening scene Accident

The last thing in the Crime Scene is opening scene Accident, after making a scene and Crime Scene TP up with a rough sketch of Measurement and Preparation of the scene Accident, then performed the opening scene.

Things to note in the opening scene Accident is the traffic flow should return to normal new police personnel / traffic cop can leave the scene Accident.

\subsection{Inquiry and investigation in case of Accident (Examination of Witnesses and suspects)}

he probe then is a series of actions Accident investigator in the case and in the manner set out in the Act - legislation to search for and collect evidence with evidence that shed light on the case Accident then happens, in order to find the criminal.

In terms of investigation and investigation, officers Accident unit will not necessarily be separated from the examination of witnesses and examination of the suspect. The witness is a person who can provide information for the purpose of investigation, prosecution and the judiciary about a criminal case is heard, seen and experienced.

The suspect is a person who because of his actions or conditions based on preliminary evidence quite reasonably suspected as criminals. BAP TSK, witnesses and Experts are equally authentic notes or writing made in a specific shape (condition) by the investigator / investigator top aide strong oath, dated and signed by the investigator / investigator maid, the suspect / witness / expert.

Terms of inspection:

- Examiner

- Has authority.

- Has enough knowledge of criminal law, criminal procedural law and other law 
- Has enough and proficient knowledge in the field of tactics and techniques Interrogation.

- Knew the cases.

- Behaviour

O believe themselves.

- No easily influenced.

$\circ$ patient and persevering and resilient.

- Can control emotions.

- Can assess accurately and objectively assess movement and attitude particularly suspect at the time said.

- The Interrogation

- In the office, home / hospital in certain respects.

- Make quiet atmosphere.

- Clear and clean.

- Safery

- Prepare the place for General Counsel.

- Started Interrogation

- On time

- After the suspect was caught immediately do the examination.

- After out Sprint detention, a suspect must begin to be examined.

- Notice the norm (Courtesy / Decency) when a suspect / witness a woman.

- Investigation by presented only those connected with the examination.

- Terms Petition.

BAP material in order to meet the answers to questions 7 namely:

- Who (people).

o The first .Who - all know about the abuse.

o Who victims of the accident.

- What (the cause).

Whether caused by the accident.

- Where (place). Where the incident occurred.

- With Do (tool). With whether the witness take the victim to the hospital.

- Why (background). Why it was committed.

- How (way). How do I do suspect after seeing the victim in the event of an accident.

- How come (time).

\section{Closing}

\subsection{Conclusion}

Thus Standards criminal investigation procedures of traffic accidents traffic unit is designed to be used as a practical guide for the execution of tasks in the field of traffic 
police officers of Pekalongan and as a parameter execution of tasks to achieve the expected target and must be justified.

\subsection{Suggestion}

Based on the description of the above discussion, the authors suggest that limiting government and police vehicles growth actively to campaign for traffic safety.

\section{Bibliography}

[1] Roni Haditijo Soemitro 1989 Metodologi Penelitian Hukum Erlangga Jakarta.

[2] Hilman Hadikusuma 1995 Metode Pembuatan Kertas Kerja atau Skripsi IImu Hukum Mandar Maju Bandung.

[3] Act No. 1 of 1946 on the Criminal Code.

[4] Act No. 08 of 1981 on the Criminal Procedure Code.

[5] Act No. 02 of 2002 on the Indonesian National Police.

[6] Act No. 22 of 2009 on Traffic and Transportation.

[7] Police Kababinkan Skep Nopol Skep / 32 / II / 2003 dated February 32003 on the Draft While Bujuklap Handling Accident scene.

[8] Skep Kabareskrim Nopol Skep / 82 / XII / 2006 / Crime December 152006 on Guidelines for the Implementation of Administrative Investigation and Investigation TP. 